\title{
ANSERJ
}

Vol. 8, No. 2

Autumn / Automne 2017

pp. $80-96$

Canadian Journal of Nonprofit and Social Economy Research

Revue canadienne de recherche sur les OBSL et l'économie social

\section{Room to Flourish: Lessons for Canadian Grantmaking Foundations from Sweden, Germany, and the Netherlands}

\author{
Nazita Lajevardi \\ Michigan State University \\ Mirle Rabinowitz Bussell \\ University of California, San Diego \\ James Stauch \\ Mount Royal University \\ Nicole Rigillo \\ McGill University
}

\begin{abstract}
While Canada has experienced a long and successful history of encouraging social participation and community activity through its grantmaking foundation sector, this article argues that Canada's historic and present-day regulatory restrictions have limited the extent to which its foundation sector has been allowed to innovate and flourish. To exemplify the types of tractable regulatory schemes that have allowed grantmaking foundation sectors in comparative contexts to prosper, the evolution of the grantmaking foundation sectors in Sweden, Germany, and the Netherlands is examined within the context of social origins theory. One important contribution of this article is to compare their regulatory frameworks to the Canadian context. It concludes with lessons learned for the Canadian grantmaking foundation sector and for public officials to consider.

\section{RÉSUMÉ}

Bien que le secteur des fondations subventionnaires au Canada ait connu une longue histoire de réussites dans l'encouragement de la participation sociale et de l'activité communautaire, cet article soutient qu'une réglementation restrictive autant dans le passé qu'au présent a limité l'innovation et l'épanouissement dans le secteur. Afin de montrer comment une réglementation plus souple pourrait permettre aux fondations canadiennes de prospérer davantage, cet article recourt à la théorie des origines sociales pour examiner le secteur en Suède, en Allemagne et aux Pays-Bas. Une contribution importante de cet article consiste ainsi à comparer les contextes réglementaires dans ces pays à celui du Canada. En conclusion, il fait des recommandations pour les fondations subventionnaires et le secteur public canadiens.
\end{abstract}




\section{Lajevardi, Bussell, Stauch, \& Rigillo (2017)}

KEYWORDS / MOTS CLÉS Grantmaking foundations; Philanthropic foundations; Sweden; Germany; the Netherlands; International comparisons; Social origins theory / Fondations subventionnaires; Fondations philanthropiques; Suède; Allemagne; Pays-Bas; Comparaisons internationales; Théorie des origines sociales

\section{INTRODUCTION}

Canadian grantmaking foundations have played an important part in seeding and funding new ideas, programs, and policies that enhance the well-being of communities. These foundations are mainly, and for the purposes of this analysis, ${ }^{1}$ registered charities that make grants to multiple other Canadian charities and to those organizations recognized by the federal government as "qualified donees" (Philanthropic Foundations Canada, n.d.). While relatively young, the Canadian grantmaking foundation sector has experienced extraordinary growth and made substantive impacts on society both in Canada and around the world. Unlike in the United States, however, where there is a long-standing body of knowledge about grantmaking foundations, very little is known about the Canadian grantmaking landscape, especially as it relates to other European examples. The body of international comparative research has not yet included Canada in its analyses. Canada's foundation sector has also not yet been extensively compared to the European context, where there is a substantial body of knowledge on foundations, led by scholars understanding foundations in a comparative context (see Moreno \& Plewes, 2007).

This article addresses an important, yet, open question in the literature: what contexts allow for Canadian foundationswhich create much of the social capital that factors into both political and economic life-to develop and thrive? While Canada has experienced a long and successful history of encouraging social participation and community activity through its grantmaking foundation sector, this article argues that Canada's historic and present-day regulatory restrictions have played a role in limiting the extent to which its foundation sector has been allowed to innovate and flourish. Anecdotal evidence reveals that many practitioners will readily admit that the more trendsetting and pioneering foundations are the ones that will run into regulatory hurdles, more so than others where the limiting factor appears to be more cultural (e.g., stemming from boards, donors, and the community context). Nevertheless, when applicable, regulatory obstacles include restrictive laws that limit foundations to giving only to other registered charities. ${ }^{2}$

The article begins by detailing the evolution of grantmaking in Canada, the state structure, the current foundation landscape, and the challenges and obstacles it faces to evaluate these comparisons. Specifically, it asks: "Do regulations in Canada actually limit the philanthropic sector?" An assessment of the constraints on the Canadian foundation sector by a stringent regulatory regime is provided. To exemplify the types of tractable regulatory schemes that have allowed grantmaking foundation sectors in comparative contexts to prosper, the evolution of the grantmaking foundation sectors in Sweden, Germany, and the Netherlands within the context of social origins theory (Salamon \& Anheier, 1998) are examined. While comparing between grantmaking foundations internationally can be difficult, since foundations can take various forms around the world (Anheier, 2001), these countries have widely been characterized as European exemplars in terms of regulatory flexibility for grantmaking foundations. As a result, grantmaking sectors can vary greatly depending on the nation in question. This analysis uses Lester Salamon and Helmut Anheier's (1998) social origins theory, which proposes that this variation is the result of more than a single factor, and that varying social and historical contexts give rise to distinct nonprofit regimes, as a theoretical framework.

The countries explored for the purposes of this analysis tend to have fewer regulatory restrictions on philanthropic activity and this has allowed the size, scope, and activity of their grantmaking foundation sectors to flourish in a manner unlike Canada. One important contribution of this article is to compare their regulatory frameworks to the Canadian context. In doing so, the current obstacles and grantmaking landscapes in each of these countries is evaluated as compared to 


\section{Lajevardi, Bussell, Stauch, \& Rigillo (2017)}

Canada. The article ultimately concludes with lessons learned for the Canadian grantmaking foundation sector and for public officials to consider.

While the origins of these varying European foundation sectors differ, the Canadian grantmaking foundation sector continues to evolve relative to them as the current Canadian government embarks on a process to "modernize" the Canadian charitable regulatory framework. For instance, Prime Minister Justin Trudeau's 2015 mandate letter to the minister of national revenue directed the Canada Revenue Agency stated:

Allow charities to do their work on behalf of Canadians free from political harassment, and modernize the rules governing the charitable and not-for-profit sectors, working with the Minister of Finance. This will include clarifying the rules governing "political activity," with an understanding that charities make an important contribution to public debate and public policy. A new legislative framework to strengthen the sector will emerge from this process. (Canada, n.d., n.p.)

Thus, key lessons about improvements to the regulatory framework governing the Canadian philanthropic sector can arguably be discerned from other countries with well-established and successful philanthropic sectors. Given that Canadian foundations are slated to play a more important and visible role in the future due to the exponential growth in intergenerational transfers of wealth, it is useful to identify exemplars that can inform how this sector can thrive and make a greater positive social, environmental and cultural impact.

\section{ORIGINS OF THE PROJECT}

This project arose from the first ever Social Sciences and Humanities Research Council (SSHRC) grant to examine the Canadian grantmaking milieu with aspirations to contribute to the scholarship and knowledge in this area. ${ }^{3}$ The Montréal Research Laboratory on Canadian Philanthropy was created in 2014 to host the SHHRC project, which was divided into four clusters. ${ }^{4}$ Cluster 4 , in particular, aims to deepen the understanding of the grantmaking foundation milieu in Canada, as compared with international trends in philanthropy elsewhere.

While the project was originally tasked with evaluating a wide range of contexts, these international comparisons were complicated due to a non-standard definition of grantmaking foundations across jurisdictions. Research shows that there is no one stable definition of grantmaking foundations throughout the comparative context. Anheier (2001) argues that foundations generally are deemed to share a common image in which the entity has a separate, identifiable asset donated for a specific purpose, which is generally public in nature. However, beyond this, foundations in Western democracies share little more in common due to the various legal traditions and systems in which they operate (Anheier, 2001). In cultivating a comparative analysis, this study also relies on a number of various sources, each of which scholars in various jurisdictions have relied on in their respective analyses. As a result, this project has adopted a broad definition of "foundations," rather than simply evaluating grantmaking foundations. It defines a grantmaking foundation at a basic level as any organization that issues grants as a significant part of its operations, and can autonomously decide, as an entity, how grants are distributed. The study also limits its focus to foundations that grant to multiple recipient organizations, and that primarily or formerly operated through grants to other organizations.

In the European context, while some have argued that a common definition of foundations is necessary, no such resolution has yet to pass. The European Foundation Centre is a membership association that argues in favour of a more cohesive operational and legal environment for European foundations that applies transnationally. It provides information on progress being made by the European Commission in adopting a European Foundation Statute. The proposed European 


\section{Lajevardi, Bussell, Stauch, \& Rigillo (2017)}

Foundation Statute, which was first presented in 2012, would define a foundation as a "public benefit purpose foundation," where each foundation would have to prove its public benefit purpose, cross-border dimension, and its possession of at least 25,000 euros in assets. Crucially, this statute would be legally recognized in all European Union member states and would operate with the same set of requirements across each of these jurisdictions. ${ }^{5}$

\section{THE EVOLUTION OF THE CANADIAN FOUNDATION SECTOR AND ITS CURRENT CHALLENGES}

Canada has experienced a long history of encouraging social participation and community activity through its grantmaking foundation sector. Yet, this history has evolved in a regionally specific manner. In Western Canada, a strong cooperative movement laid the groundwork for strong community philanthropy, giving rise in some cases to well-endowed foundations, such as the Vancouver Foundation and the Winnipeg Foundation, the largest and oldest community foundations, respectively. In French-speaking Canada, the influence of the Roman Catholic Church meant that giving was largely organized by and through the church up until the middle of the twentieth century. In the 1960s, the landscape of the French-speaking Canadian foundation sector changed. The decline in the powers of the church as well as challenges to the social, political, and economic dominance of the Anglophone community in Québec during this time meant that the francophone foundation sector emerged fairly late, in the 1980s, with the rise in the fortunes of the francophone business elite. Meanwhile in Western Canada, American foundations also played an important role in disbursing philanthropic funds and in developing public institutions in Canada, particularly in the early twentieth century (O'Halloran 2012). Foundation philanthropy also has a very metropolitan character, with the vast majority of well-endowed foundations based in one of four centres: Toronto, Montréal, Vancouver, and Calgary.

Today, Canada has a well-developed welfare state that spends tens of billions of dollars annually on health, education, and social services. It also has a well-developed and growing philanthropic infrastructure, which is predicted to grow as the roles and responsibilities of government begin to shift in the years to come (Monitor Institute, 2014). While the Canadian regulatory environment for philanthropy has been described as "relatively hospitable" (Patten \& Pearson, 2010), especially given that the process for registering a foundation is fairly straightforward, attempts to make it more flexible for charities have recently been thwarted (Golombek, 2016).

Additionally, given that it is in its early stage of professional development, the scale of the Canadian foundation means the use of sophisticated grantmaking approaches in Canada is limited, with some notable exceptions (Patten \& Pearson, 2010). In the last twenty years, the number of Canadian foundations has increased dramatically. From 1994 to 2014, the number of private foundations increased by 76 percent to just over 5,300 , while the number of public foundations has increased by 69 percent to about 5,100 foundations. This results in a total of almost 10,500 foundations (Imagine Canada \& PFC, 2014). Although this figure refers to all charitable foundations, including public and private foundations, which held combined assets of $\$ 55$ billion and made grants totaling $\$ 4.6$ billion in 2003 (PFC, 2014). Of these grants, education, research, health, and social services formed the highest percentage of total grant value by funding area, constituting a total of 59 percent of grant value (PFC, 2014).

Nevertheless, the Canadian foundation sector faces several constraints. These are in part related to regularly restrictions rather than public attitudes, which are generally positive and supportive of philanthropy (Patten \& Pearson, 2010). Obstacles include restrictive laws that limit foundations to giving only to other registered charities or public entities defined by the Income Tax Act, which are defined according to centuries-old definitions that exclude many organizations from tax-receipted giving (Patten \& Pearson, 2010). Moreover, the number of foundations with an international lens in Canada remains fairly limited, with nearly half of all Canadian overseas grants coming from one foundation: the MasterCard Foundation, which may be at least partially due to the Canada Revenue Agency's (CRA) restrictions that limit grants 


\section{Lajevardi, Bussell, Stauch, \& Rigillo (2017)}

made across borders to only "qualified donees." The "qualified donees" include only a limited set of organizations, including Canadian registered charities, a small number of universities outside Canada, the United Nations, and its agencies, and a very small number of foreign charities (Blumberg, 2009).

Inflated interpretations about these restrictions further exacerbate the constraints on what Canadian foundations can accomplish. This is due in part to the political activities restriction, or the "ten percent" rule, which specifies that the nonpartisan advocacy activities of charities can account for only ten percent of the foundation's budget. While it remains unclear whether the "ten percent" rule has resulted in a chill factor and how this might have affected the philanthropic sector's "embeddedness" in society, it has in turn led to complaints that the rule is a complex form of regulation, which arguably reorients the activities of foundations away from political activities and toward other concerns of the nonprofit sector (McGann \& Johnson, 2005). Certainly, this can be construed as a way to avoid the channeling of private wealth through foundations towards a greater influence of politics. The new restrictions on foundations were imposed in 2015 establishing that those grant monies used by donees for political activities must also be counted by the foundation toward its ten percent quota. This means that political activity supported through foundation grants to other donees is effectively "double-counted," doubly reinforcing political restrictions on the foundation sector is doubly reinforced. ${ }^{6}$

\section{THE CURRENT DEBATE SURROUNDING REGULATORY LAWS AND THE CANADIAN FOUNDATION SECTOR}

This section provides an overview of the debate surrounding the current state of the regulatory sector governing Canadian foundations. The Liberal government, elected in late 2015, created a wave of expectations with respect to supporting a thriving philanthropic sector. The mandate letter from the prime minister to the minister responsible for the Canada Revenue Agency asked the Ministry to "modernize the rules governing the charitable and not-for-profit sectors" and to create a "a new legislative framework to strengthen the sector" (Canada, n.d.). Leading up to this, throughout the 2015 election campaign, the Liberal party platform also promised to change the regulatory laws putting donations of the proceeds from the sale of appreciated private corporation shares or appreciated real estate on a similar footing as donations of publicly traded securities (Glombeck, 2016). This would have greatly incentivized the philanthropically inclined to make major gifts to Canadian charities in 2017 and beyond (Glombeck, 2016).

Prior to the election, Canadian charities experienced an "advocacy chill" (Beeby, 2016) under the Conservative government, by being subjected to unprecedented levels of audits by the CRA. In 2015 alone, 54 charities were subject to the CRA political-activities audits, and five of those charities were given notice that they would lose their charitable registrations (Beeby 2016). ${ }^{7}$

Logistical hurdles under the Conservative government, such as the ones mentioned in the CRA's announcement above, have unnecessarily impeded, and in a few instances halted, the ability of charities across Canada to perform their functions. Many Canadians expected the "advocacy chill" that many charities experienced under the Conservative government to warm under the Liberal government. While the Liberal government made good in many respects on its promise to focus on economic growth, job creation, and support for a strong middle class, it crucially reneged on a promise that was first announced in the 2014 Federal Budget announcement that there would be a review of tax exemption status for nonprofit organizations under paragraph 149(1)(I) of the Income Tax Act (Carter et al., 2016). Not only did the newly elected Liberal government go back on this promise by quietly announcing in its budget published in March 2016 that it was not proceeding with draft legislation exempting capital gains from tax when the proceeds from the sale of real estate or private company shares are donated to a registered charity (Glombeck 2016). For a long time, it also had done nothing to end the "political harassment" that Canadian foundations experience in the form of tax audits (Beeby, 2016). As of the time of this writing, these audits have been suspended. Nevertheless, the optimism that the Canadian foundation sector once 


\section{Lajevardi, Bussell, Stauch, \& Rigillo (2017)}

held with the rise of the Liberal government had translated to disappointment in the cancellation of these proposed changes. Imagine Canada, the umbrella organization for many registered Canadian charities, published an open letter in March 2016 in response to this cancellation, stating in part:

The decision not to proceed with the income tax exemption in respect to capital gains of the donation of real estate and shares of private corporations sends a troubling message related to the creation of a regulatory environment that will enable charities to thrive, fulfill their missions and continue to be a powerful contributor to the economic well-being of this country (Emmet \& MacDonald, 2016).

Many contend that the proposed changes in the regulatory laws surrounding donations to registered charities would have had a large impact on the ability of the Canadian foundation sector to flourish. While this severely limits the ability of Canadian foundations to fulfill their mandates, it also has stark and direct implications for the Canadian economy. Canadian charities constitute a dynamic and creative part of the economy, accounting for approximately eight percent of the Gross Domestic Product (GDP) and employing two million people (Emmet \& MacDonald, 2016). This potential constraint can either reduce or limit the ability of Canadian foundations to operate more freely in the future, an unobserved phenomenon and constraint for many of the European charities explored in this article.

\section{SOCIAL ORIGINS THEORY APPLIED: THE EVOLUTION OF THE FOUNDATION SECTOR IN SWEDEN, GERMANY, AND THE NETHERLANDS AND THEIR CURRENT GRANTMAKING LANDSCAPES}

Civil society organizations, including charitable and other nonprofit entities have played a critical role in producing social capital throughout the world (Putnam, 1993). ${ }^{8}$ They contribute to political and economic life by providing public goodsoften when governments cannot. How these sectors develop, however, has been subject to much debate. This article uses the social origins theory developed by Salamon and Anheier (1998). Social origins theory argues in large part that a given nonprofit sector's "embeddedness" in society can be traced through broader social, political, and economic realities. Under this framework, choices about whether to rely on market, nonprofit, or state provision of key services are not simply made freely by consumers in an open market. Instead, these choices are heavily constrained by prior patterns of historical development that have significantly shaped the range of options available to the consumer (Salamon \& Anheier, 1998).

While this approach makes the study of nonprofit sectors more complex than other theoretical frameworks, it also integrates many aspects of social relations that are largely ignored under other paradigms. The social origins theory, thus, is a complex framework that incorporates the historical and economic development of a given nonprofit sector and argues that distinct sectors can be traced to an identifiable set of social circumstances (Salamon \& Anheier, 1998).

Using social origins theory, this article contends that in different comparative contexts and countries, foundations were established to serve different functions. European foundations, for instance, were historically instituted against the backdrop of delivering services, whereas American foundations rose to fill financial and redistributive roles. Unlike other nation-states, which experienced a more uniform evolution of their grantmaking foundation sectors, Canada saw its grantmaking foundation sector evolve differently in French-speaking versus English-speaking regions. In the Frenchspeaking province of Québec, the influence of the Catholic Church meant that up until the mid-twentieth century, foundations were irrelevant given that the church already offered most philanthropic services. In English-speaking Canada, business interests and a strong cooperative movement laid the groundwork for strong community philanthropy and even a small number of well-endowed foundations well before the 1950 s. 


\section{Lajevardi, Bussell, Stauch, \& Rigillo (2017)}

The development of the foundation sectors in Sweden, Germany, and the Netherlands evolved differently than in Canada. In the next section, Salamon and Anheier's (1998) social origins theory framework is used to trace the evolution of these foundation sectors and identify points of contrast with the Canadian context. This ultimately identifies the set of social circumstances that has allowed the nonprofit sectors in these contexts to thrive and innovate.

Perhaps defying conventional expectations of strong social welfare states where we might expect more regulation and government involvement and oversight, in each of these three European countries, the lack of regulatory restrictions on philanthropic activity has allowed the size, scope, and activity of the foundation sector to flourish in a manner unlike Canada. While the foundation sectors in these countries are more likely than in Canada to be connected to a veto player (such as a government or a private institution) that limits their ability to autonomously determine the extent to which the foundation has control over their objectives, policies, or projects, there is paradoxically very little regulatory intervention that impedes foundations' ability to act and innovate. While not constituting formal constraints, these states may be in fact be more regulated by other veto players. By examining the evolution of the grantmaking foundation sector in Sweden, Germany, and the Netherlands and by comparing their regulatory frameworks to the Canadian context, it is possible to offer a series of regulatory lessons for the Canadian grantmaking foundation sector and public officials.

Today, Canada is a mature welfare state that expends tens of billions of dollars on health, education, and social services. In the same vein, it fosters a well-developed and growing philanthropic infrastructure, which is predicted to grow as the roles and responsibilities of government begin to shift in the coming years (Monitor Institute, 2014). According to a 2014 study of the largest Canadian grantmaking foundations by Imagine Canada and PFC, education and research, health, and social services formed the highest percentage of total grant value by funding area, constituting a total of 59 percent of grant value. International grantmaking, however, remains a relatively underdeveloped practice in Canada due to regulations restricting international giving. Between 1997 and 2008, public foundations gave a total of nearly CAD \$300 million to international causes, out of a total of nearly CAD $\$ 45$ billion in expenditures, or merely 0.67 percent of total expenditures.

Table 1 compares the current foundation landscapes in Sweden, Germany, and the Netherlands to Canada as of 2015. For the sake of comparison, this includes both foundations that make grants to multiple recipients and those that grant to one dedicated recipient (such as a hospital or university foundations).

\section{Table 1: Comparative comparisons and descriptives ${ }^{9}$}

\begin{tabular}{|l|c|c|c|c|}
\hline \multicolumn{1}{|c|}{ Country } & $\begin{array}{c}\text { Number of foundations, } \\
2015\end{array}$ & $\begin{array}{c}\text { Expenditures, } \\
2015\end{array}$ & $\begin{array}{c}\text { Population size, } 2015 \\
\text { (in millions) }\end{array}$ & $\begin{array}{c}\text { Per capita expenditures } \\
\text { (in Euros) }\end{array}$ \\
\hline Canada & 10,500 & $\begin{array}{c}€ 3.312 \text { billion } \\
\text { (CAD \$4.6 billion) }\end{array}$ & 35.85 & 92.38 \\
\hline Sweden & $13,700-25,000$ & $€ 600$ million & 9.80 & 61.23 \\
\hline Germany & 19,150 & $€ 17$ billion & 81.69 & 208 \\
\hline The Netherlands & 7,500 & $€ 6$ billion & 16.94 & 354.19 \\
\hline
\end{tabular}

As Table 1 demonstrates, with respect to the size of each of their nonprofit sectors and as of 2015, Sweden is estimated to have between 13,700 to 25,000 foundations (depending on the type of measurement, see Schlüter et al., 2001 and 


\section{Lajevardi, Bussell, Stauch, \& Rigillo (2017)}

Wijkström \& Einarsson, 2004), ${ }^{10}$ Germany has 19,150 foundations-more than any other country in Europe (Observatoire de la Fondation de France, 2015), and the Netherlands has 7,500 foundations. With respect to expenditures and in 2015, the foundation sector in Sweden expended $€ 600$ million, the sector in Germany expended $€ 17$ billion, and the sector in the Netherlands expended $€ 6$ billion. As of 2014, Canada, meanwhile, is estimated to have approximately 10,500 private and public foundations and to have expended approximately $\$ 4.6$ billion. When examining per capita dollars in 2015, however, the Netherlands appears to have the most assets per capita, followed by Germany, Canada, and Sweden.

\section{A COMPARISON OF THE EVOLUTION OF THE CANADIAN AND SWEDISH FOUNDATION SECTORS}

Sweden's political economy embodies the social democratic model in which working-class elements were able to exert effective political power, albeit typically in alliance with other social classes. Similar to French-speaking Canada, working-class political parties in mid-twentieth-century Sweden were able to push for extensive social welfare benefits from the state as a matter of right in the context of a weakened, state-dominated church and a limited monarchy. During the second half of the nineteenth century, Sweden was a relatively poor country that experienced difficulties in development due to the extensive emigration of its inhabitants to North America (Wijkström \& Einarsson, 2004). Yet, due to its large share of natural resources, such as iron and timbre, and its access to cheap hydro energy, Sweden was able to industrialize during the twentieth century, avoid engagement in costly wars, and develop a solid middle class. Its ability to shift from an agrarian economy to an industrial one translated into an accumulation of wealth in the country. Moreover, given subsequent high tax regimes under the Social Democrats, Sweden has also experienced a large growth of public wealth resulting in a strong state-supported social service network (Wijkström \& Einarsson, 2004). This growth was particularly reinforced by Sweden experiencing long periods of peaceful relations between actors in the labour market (Wijström \& Einarsson, 2004). Under the social origins theory, these historical factors are largely important in explaining the growth and development of Swedish foundations.

This discussion of Sweden's foundation sector refers specifically to its nonprofit sector. Today, the Swedish nonprofit sector performs a different function in social democratic regimes-one of advocacy and personal expression, rather than service-provision. In Sweden, a very substantial network of volunteer-based advocacy, recreational, and hobby organizations turns out to exist alongside a highly developed welfare state. In this kind of setting, the nonprofit sector may actually come closest to the ideal of a "civil society" sector functioning to facilitate individual and group expression (Salamon \& Anheier, 1998).

In Sweden, three types of legal entities are entitled to a more favourable position than other legal entities, namely foundations, nonprofit associations, and registered religious communities. First, a foundation is defined as a holding of assets that has been set aside permanently by one or more individuals or legal entities for a permanent or long-term given purpose. The foundation must be administrated by a board of its own or by an existing body (linked administration), such as a university, an authority, or another foundation. Moreover, as far as legal capacity is concerned there is no act of registration. Sweden's foundations have very flexible mandates since they can have any purpose at all, as long as they are not in conflict with the law or moral standards. If the purpose of the foundation is to promote public service activities, the foundation is known as a public foundation. Second, Sweden recognizes nonprofit associations, which become legal entities from the moment they are set up. For an association to exist in the legal sense, it is necessary for a number of individuals or legal entities to have entered into an agreement to act jointly in an organized form for a given period of time or until further notice to meet a common, nonprofit purpose. For an association to be a nonprofit association it must pursue non-commercial activities for either non-commercial purposes or purposes that promote the financial interests of 


\section{Lajevardi, Bussell, Stauch, \& Rigillo (2017)}

its members. Third, Sweden has registered religious communities, which are associations meant for religious activities, which includes arranging religious services.

Today, both Canada and Sweden have sizable foundation sectors that have begun to fill the role previously played exclusively by the state when it comes to providing services to the greater population as a whole, not just marginalized communities, and not on an individual basis. In 2015, Canada was estimated to have nearly 11,000 private and public foundations (Philanthopic Foundations Canada, n.d.) while the estimated number of Swedish foundations ranges from 13,700, (Study on Volunteering in the European Union Country Report Sweden) to 25,000 foundations depending on the measurement of the type of foundation (Schlüter et al., 2001). ${ }^{11}$ In certain provinces in Canada, the state did not stand as much of a roadblock to the emergence of a strong foundation sector. As previously mentioned, rather, a strong cooperative movement originally laid the groundwork for strong community philanthropy, giving rise_-particularly in Western Canada as a whole_to the institutional form of community foundations. In Sweden, it was the various levels of government that established many foundations during the second part of the twentieth century. Filip Wikström and Stefan Einarsson (2005) estimate that of the 11,500 foundations in Sweden 2005, almost half $(4,720)$ were government-related foundations, which include a wide variety of foundations connect to public "host bodies," such as public hospital controlled foundations or ones connected to the royal family or Swedish nobility (Wikström \& Einarsson, 2005). This is well in line with the logic that in a country with a high-tax regime, various public sector actors were generally able to accumulate substantial resources. Thus, it is often the case that state or local municipalities have been the founder of foundations in Sweden (Schlüter et al., 2001). While this is also the case in Canada, in limited numbers, they are more likely to be in place in Sweden.

Today, Sweden boasts an incredibly malleable and large foundation sector, though it is only a fraction of the size of Canada's sector when viewed on a per capita basis. While Canada allows for some flexibility for its foundations, it by no means has regulatory laws that are as flexible as the Swedish context.

According to the various scholarly estimates, Sweden has one of the largest foundation sectors in all of Europe. This is partially due to the fact that Sweden has very fluid and flexible standards to determine what constitutes the legal entities that serve the needs of its population. Moreover, due to the ease with which these charitable organizations may exist, Sweden has one of the highest densities of associations worldwide: on average, every adult belongs to nine associations (Lundström \& Wijkström, 1997). Thus, Sweden serves as an important example of the heightened social capital that a country can channel into its foundation sector with very flexible and limited regulations.

\section{A COMPARISON OF THE EVOLUTION OF THE CANADIAN AND GERMAN FOUNDATION SECTORS}

In Germany, a close working relationship exists between the state and nonprofit organizations and has eventually resulted in the coexistence of a sizable nonprofit sector and an extensive social welfare state (Salamon \& Anheier, 1998). Upon conducting a comparison of the German and the Canadian sector, it is important to consider Germany's population sizenearly 80 million-more than double that of Canada. Correspondingly, then, Germany has double the number of foundations found in Canada, but when examined on a per capita basis, it is about the same as the Canadian sector. As previously noted, the foundation sector in Germany is broadly referred to as the nonprofit sector. The German nonprofit sector, unlike the more recent Swedish and Canadian milieus, has been institutionalized in German society since the 1800s. German foundations were formed in the nineteenth century in the wake of the accumulation of private wealth, a highly developed_though regulated—welfare state, and industrialization (Anheier et al. 2015; Zimmer and Bräuer 2014). However, due to political forces, the sector has seen periods of suffering throughout its existence. To understand how the German foundation sector has evolved under a social origins theory framework, it is critical to consider that Germany has undergone three historical periods that have greatly shaped its current landscape. 


\section{Lajevardi, Bussell, Stauch, \& Rigillo (2017)}

First, prior to the 1800s and in the early medieval period, elite families established foundations mainly to meet religious, charitable, and health purposes (Anheier et al., 2015). Second, between the mid-1800s and the end of World War II, the foundation sector grew slowly as wealth accumulated due to industrialization. After the Second World War, however, very few foundations survived and remained intact. It was not until the third period, near the end of the Cold War in the 1980s, that the vast majority of today's foundations were established. Thus, while the sector suffered throughout the first half of the twentieth century due to two wars, Nazi rule, and communism, it has since experienced extraordinary growth (Anheier et al., 2015).

In the last period of growth since the 1980s, hundreds of private charity organizations and social service institutions financed by donations and membership dues came into existence (Zimmer, Appel, Dittrich, Lange, Sittermann, Stallmann, \& Kendall, 2005). While German social entrepreneurs in this latter period emerged in the context of a highly developed, highly regulated welfare state, the state was careful to redistribute a large portion of its wealth to society without simultaneously imposing complex regulatory schemes. While many German foundations $(2,243)$ were set up in the twentieth century and in the context of industrialization between 1901 and 2000, Anheier et al. (2015) find that only slightly fewer foundations $(2,017)$ were established in a comparatively shorter time period: between 2001-2013. Today, Germany has the largest foundation sector in all of Europe. Given the drastic growth of philanthropy throughout the twenty-first century, the German context is worthy of examination for Canadian scholars who wish to draw lessons on how to foster similar growth in the Canadian context. One benefit of Salamon and Anheier's (1998) social origins theory is that it helps explain apparent anomalies in the relationship between the growth of government and the growth of the nonprofit sector. With respect to Germany and under this framework, then, the ebbs and flows in the size, scale, and purpose of the foundation sector largely mirrored the social, economic, and political context at that time. As such, much of the rise of the foundation sector can be attributed to the state handing a large portion of wealth back to society and without much regulation.

German foundations maintain institutional forms that do in fact greatly resemble Canadian foundations. For instance, neither Canadian nor German laws have instituted a minimum initial asset requirement to form foundations. Moreover, both Germany and Canada have well-developed welfare systems that spend tens of billions of dollars on health, education and social services each year. The difference in limitations for foundations in the two countries is that Canadian foundations are more restricted than their German counterparts in that they may only provide funding to other Canadian charitable organizations-a limitation that may be hindering their ability to perform a more geographically diverse range of charitable activities (Council on Foundations, 2017).

Under German law today, a foundation (Stiftung) is a legal entity whose earnings on assets are used to pursue a specific purpose set forth by the founder. Foundations can either be grantmaking, operating, or both as long as they have a legal personality, which they receive upon recognition by the competent authority in the state (Bundesland) in which the foundation seeks to be headquartered (Anheier et al., 2015). Unlike other European contexts, the Civil Code does not require a specific initial amount to form a foundation, though it does require that the permanent and sustainable promotion of the foundation's purpose appear to be assured. However, they are subject to state supervision. Foundations must file annual reports to their respective state supervisory authority to acquire approval for its various functions.

Today, the German and Canadian foundation sectors also differ with respect to their relative size, assets, and expenditures per annum. As of 2015, Germany has 19,150 foundations-more than any other country in Europe according to a recent study on the European philanthropic sector by the Observatoire de la Fondation de France (2015)_although arguably less than Canada on a per capita basis. In 2014 alone, German foundations spent 17 billion euros, 74 percent of which was spent on international and humanitarian aid (Observatoire de la Fondation de France, 2015). Thus, German foundations gave 24 percent of their total assets during this time (Observatoire de la Fondation de France, 2015). 


\section{Lajevardi, Bussell, Stauch, \& Rigillo (2017)}

However, this is not to say that Canada is not experiencing growth of its own. From 2002-2012, the total assets held by the largest 150 Canadian grantmaking foundations more than doubled, increasing from just over $\$ 8.8$ billion in 2002 to $\$ 18.7$ billion in 2012 (Imagine Canada, 2014). This growth in assets is also reflected in an increase in Canadian foundation spending. During this time, Canadian foundations increased their spending from \$558 million in 2004 to \$966 million in 2012, reflecting a growth of 73 percent in expenditures (Imagine Canada, 2014). Importantly, while the Canadian foundation sector has grown dramatically, it can benefit from attempting to mirror the expenditures observed in the German sector.

\section{A COMPARISON OF THE EVOLUTION OF THE CANADIAN AND DUTCH FOUNDATION SECTORS}

The evolution of Canadian and Dutch foundations has undergone starkly different trajectories. While Canadian foundations evolved to work in parallel with the state to provide public goods, the Dutch foundation sector developed in a much more entwined manner with the government in a process known as "pillarization." Similar to many other Western European countries, the history of the Dutch nonprofit sector can be tracked to medieval times where churches and religious congregations provided the institutional roots of the sector (Burger \& Dekker, 2001; Veldheer \& Burger, 1999). During the twentieth century, in contrast, the strong growth of the nonprofit sector was largely due to the close ties between the private nonprofit agencies and the government. Pillarization ensured that Dutch foundations and the state worked together to provide services to the masses.

Under a social origins theory framework, pillarization originally began in the second half of the nineteenth century, when the citizenry organized itself along religious and political lines and resulted in a variety of denominational organizations, such as political parties, trade unions, schools, hospitals, and sports clubs (Burger \& Dekker, 2001). This organization of individuals into various groups and associations eventually evolved into the modern-day Dutch foundation sector. Nevertheless, the Netherlands experienced a sharp decline in its pillarized institutions in the 1970s, when new laws were implemented by the state regulating the financial contributions made to private nonprofit organizations as a result of significant shifts in the national political sphere (Burger \& Dekker, 2001). This trend was ultimately reversed, however, when both major Dutch parties supported the dissolution of state holdings and the reduction of public regulation and public expenditures in an effort to empower the nonprofit sector (Burger \& Dekker, 2001).

Pillarization refers to the "vertical" mediating functions between foundations and the state in providing services to the citizenry. These foundations, in turn, perform a dual function: they represent the interests of their specific group in politics and also are of service to the government by implementing and monitoring its policies (Burger \& Dekker, 2001). In other words, private organizations provide many services in education, healthcare, and welfare, but are financed through public funds (Burger \& Dekker, 2001). For example, and as Ary Burger and Paul Dekker (2001) note, only about 30 percent of students receive their education at public schools in the Netherlands; the others attend private schools, which the Ministry of Education finances almost entirely. Under social origins theory, one can consider pillarization to have had some major and long-lasting impacts on Dutch society_in addition to the current grantmaking landscape in place today. Pillarization has allowed the Netherlands to remain a peaceful and stable democracy, despite sharp divisions between pillars in society, which were resolved at the top levels by elites (Burger \& Dekker, 2001; Daalder, 1984; Lijphart, 1968).

The foundation sectors in Canada and the Netherlands resemble one another in scope and in average yearly expenditures. Given the available estimates, the Netherlands has approximately 7,500 foundations and expended $€ 6$ billion in 2015. The grantmaking culture in the Netherlands, however, is largely different than in Canada, due to lax regulatory laws that have allowed a great portion of the population to contribute to the charitable sector. In the Netherlands, giving and grantmaking are an integral part of Dutch society for individual donors and companies, alike. In 2013, 85 percent of the Dutch population was a donor to a nonprofit, while 71 percent of Dutch companies also donated to charitable foundations (Observatoire de 


\section{Lajevardi, Bussell, Stauch, \& Rigillo (2017)}

la Fondation de France, 2015; Schuyt et al., 2015). In addition, in 2013, it was estimated that 38 percent of Dutch society devotes an average of 21 hours a month to voluntary work (Observatoire de la Fondation de France, 2015).

The flexibility of laws surrounding Dutch donations has certainly played an integral role in fostering an atmosphere in which such a high percentage of Dutch individual and corporate donors are able to contribute to the charitable sector.

Yet, one of the most unique features of the Dutch welfare state is that private nonprofits deliver many services that are collectively funded in partnership with the state, while simultaneously fostering a lax regulatory regime in which donors regularly donate to the nonprofit sector and devote their time to voluntary work. So while the Dutch foundation sector roughly resembles Canada in scope and size, it interacts with the state to collectively deliver goods (Burger \& Dekker, 2001), similar to publicly contracted and mandated charities in Canada (e.g., universities, hospitals, distress centres, employment development agencies, and child advocacy centres). In fact, the Dutch foundation sector is greatly responsible for the delivery of public goods while the government is largely responsible for the financing of these services. The delivery of education is a great example. Only 30 percent of primary and secondary school students receive their education at public schools (Burger \& Dekker, 2001). The others attend private schools, administered by foundations, but financed exclusively by the Ministry of Education (Burger \& Dekker, 2001). The only public good that is solely administered by the Dutch government without the involvement of the foundation sector is the delivery of social security arrangements (Burger \& Dekker, 2001).

The relative size, assets, and expenditures of the Dutch grantmaking landscape mirror the Canadian example. Canada has a larger foundation sector than the Netherlands, but the expenditures by each country's sector do not differ significantly. As of 2014, Canada was estimated to have around 10,500 private and public foundations, while the Netherlands had 7,500 foundations. Recall that Canadian foundations hold assets totaling $\$ 55$ billion dollars, $\$ 4.6$ billion of which they spent in 2014 (Philanthropic Foundations Canada, n.d.). This results in an 8.3 percent expenditure to asset ratio. Likewise in 2014, Dutch foundations expended 6 billion euros, yielding an 8 percent expenditure to asset ratio (Observatoire de la Fondation de France, 2015).

Despite these similarities, the Dutch model is much more successful at integrating the foundation sector into public service provision than the Canadian one. This integration requires foundations to restrict their activities to those in the domain of public service provision, which is governed by its own set of regulations. One way to view the Dutch foundation sector is to consider it less restrictive. Both major Dutch political parties have supported efforts to reduce regulation on the nonprofit sector in order to increase pillarization with the government to deliver public goods. But similar to Canada, where restrictive laws dominate how foundations may be formed and how contributions may be made, the Netherlands has long protected the individual's right to associate since its 1848 Constitution. Every Dutch citizen enjoys the right to form associations, foundations, and churches—all of which serve as conduits for nonprofit activities (Burger \& Dekker, 2001).

Moreover, Dutch foundations differ from Canadian foundations, in that they must not be wholly private (Burger \& Dekker, 2001). In other words, many Dutch foundations fall into categories that are largely, if not mostly, financed from public resources, whereas most Canadian foundations receive private donations from individual citizens or companies. ${ }^{12}$ In other words, being financed by public resources likely translates to different accountability mechanisms, and possibly less of a need for strong regulation. Similarly, while Canadian foundations spend the highest percentage of total grant value in the areas of education and research, health, and social services, Dutch foundations spend most of their resources on healthcare, development and housing, and education and research (Burger \& Dekker, 2001). The one key difference is the Dutch foundation sector's focus on housing, which stems from the fact that of the six million dwellings in the country, half are rented homes, of which nonprofits own more than two million of them (Burger \& Dekker, 2001). Thus, one-third of all privately owned homes and two-thirds of all rented homes belong to nonprofits (Burger \& Dekker, 2001). 


\section{Lajevardi, Bussell, Stauch, \& Rigillo (2017)}

Finally, the Dutch government has at times established some private foundations for the purpose of performing certain functions. Foundations that are government-run are only deemed to be foundations by Dutch scholars when the government appoints at least half of the board (Burger \& Dekker, 2001). The World Radio Broadcasting Service, for instance, is one such foundation. The Dutch government created this government foundation with the purpose of informing Dutch people living abroad either permanently or temporarily (Burger \& Dekker, 2001).

\section{CHALLENGES AND OPPORTUNITIES IN THE SWEDISH, GERMAN, AND DUTCH GRANTMAKING FOUNDATION SECTORS}

This article has thus far argued that Canada faces numerous challenges with respect to its regulatory restrictions by providing a comparative analysis with Sweden, Germany, and the Netherlands under the social origins theory. In Canada, the Income Tax Act restricts foundations to only being able to give to other registered charities and other qualified donees.

While there are nearly 90,000 registered charities in Canada, the definition of "charitable" remains restricted to the original Elizabethan Poor Laws definition, with ad hoc additions based on the (slow) evolution of common law (Patten \& Pearson, 2010). Canadian foundations engaged in international giving also are fairly limited by the CRA's restrictions that confine grants made across borders to only "qualified donees."13

Consequently, only three percent of foundation funding in Canada is allocated to international activities (Moreno \& Plewes, 2007), which also has the effect of making the character of Canadian philanthropy unduly parochial, compared to other countries. Similarly, Canadian grantmaking foundations are limited in donations to individuals, unless the giving takes the form of a scholarship (and even then it must meet certain requirements). The ownership and operation of social businesses is thus much more challenging than it is in other contexts, such as in the U.S. and in Europe (Monitor Institute, 2014). Finally, the large-scale, and often inaccurate, perceptions about Canadian foundations' limited abilities further exacerbate constraints on what Canadian foundations are actually able to accomplish (Blumberg, 2009; Monitor Institute, 2014). While this article provided a comparative analysis with Sweden, Germany, and the Netherlands, it nevertheless recognize that these comparative contexts also face numerous challenges and opportunities. The next section provides a comparison of the challenges and opportunities faced by the Canadian sector in contrast to each of these comparative contexts.

\section{A COMPARISON OF THE CHALLENGES AND OPPORTUNITIES FACED BY THE CANADIAN AND SWEDISH FOUNDATION SECTORS}

In Sweden, the foundation sector has traditionally been intended to complement the welfare state (Wijkström \& Einarsson, 2004). As a result, the tax and regulatory regime has always been flexible, and at times informal. Up until the mid-1990s, no law had regulated the institutionalization of Swedish foundations as much as the Foundation Law (1994), which came into effect in 1996 and implemented somewhat more stringent requirements for the formation of foundations (Wijkström \& Einarsson, 2004). During this time period, there was also an overhaul of the tax regime for foundations that made it slightly more difficult for charitable organizations to be considered charities and to receive tax breaks (Carlsson \& Stenman, 2003; Wijkström \& Einarsson, 2004).

\section{A COMPARISON OF THE CHALLENGES AND OPPORTUNITIES FACED BY THE CANADIAN AND GERMAN FOUNDATION SECTORS}

Germany and Canada experience dissimilar institutional challenges to their grantmaking endeavours. While the growth of German foundations is limited in relation to its strong welfare state, the growth of the Canadian foundation sector is limited in part because of regulatory barriers, as a result of conservative and risk-averse foundation boards and cultures. In addition, 


\section{Lajevardi, Bussell, Stauch, \& Rigillo (2017)}

a great deal of foreign aid work is taken off the table for Canadian foundations because Canadian foundations are not permitted to carry out their own international activities unless these activities can also be contracted to another organization (agent) while maintaining that the Canadian organization is the active and controlling partner (Moreno \& Plewes, 2007).

In contrast, the expenditures of German foundations were high, with Fondation de France estimating that the nearly 19,150 German foundations expended €17 billion in 2015 (Observatoire de la Fondation de France, 2015). Yet, while Germany has experienced unprecedented growth in the number of foundations being instituted over the past decade, its strong welfare state continues to slow the rise of social enterprises compared to other more liberal welfare systems (Wolf, 2014). Today, German society continues to debate the position and role of social enterprises within the welfare state. Finally, there is very little information about the actual impact of German foundations.

\section{A COMPARISON OF THE CHALLENGES AND OPPORTUNITIES FACED BY THE CANADIAN AND DUTCH FOUNDATION SECTORS}

The Dutch foundation sector is much more flexible than Canada's. The Canadian foundation sector is largely disadvantaged with respect to the large regularly restrictions that limit the ability of its foundations to easily perform a myriad of activities (Patten \& Pearson, 2010).

The Netherlands, on the other hand, has a great deal of flexibility in the regulation of its foundation sector. As a result, the foundation sector and private firms compete to deliver services to the citizenry, which has in turn created a large number of options (Burger \& Dekker, 2001). Nevertheless, the future of the Dutch nonprofit sector may be affected by the increasing interdependence between European Union member states. Today, the Netherlands is an example of a state in which favourable tax treatments and the delivery of government services have allowed the foundation sector to prosper. Yet, as the EU considers codifying policies that may put an end to this Dutch favourable foundation sector, there may be real and detrimental impacts on healthcare (Burger \& Dekker, 2001).

European Union member states are largely responsible for their own healthcare systems. Nevertheless, a number of studies and rulings by European courts have called into question the long-term tenability of national healthcare systems (Burger \& Dekker, 2001). They suggest that moving from a national to a more European-centralized healthcare arena may be in the best interest of the EU and may come into place in the very foreseeable future (Burger \& Dekker, 2001). This poses a great deal of tension for the Netherlands, where open competition between healthcare providers and notions of consumer choice are valued and where private firms and foundations are both responsible for delivering these services (Burger \& Dekker, 2001).

\section{CONCLUSION}

This article explores the various contexts that allow for Canadian foundations to develop, thrive, and innovate, by providing a comparative analysis with Sweden, Germany, and the Netherlands. It argues that Canada's historic and present-day regulatory restrictions have imposed some constraints on the extent to which its foundation sector has been allowed to flourish. In contrast to Canada, the comparative contexts explored here offer more flexibility to the foundation sector and a relatively lower level of regulatory restrictions on philanthropic activity. Under social origins theory, the development of the foundation sectors and the subsequent lax regulatory regimes in those states are responsible for allowing the size, scope, and activity of the foundation sectors in those countries to flourish in a manner unlike Canada. As Canada's population diversifies, and as it becomes less tethered to its British and French institutional and social origins, the ability to adapt and embrace lessons from other countries should, in theory at least, strengthen over time. 


\section{Lajevardi, Bussell, Stauch, \& Rigillo (2017)}

On the bright side, when one examines per capita spending, it is clear that Canada's foundation sector is spending much more per capita than European countries that are typically considered to be leaders in the philanthropic world. Perhaps one important suggestion for future research, then, is for scholars to place more of an emphasis on per capita expenditures rather than mere sums spent. As highlighted in the evidence above, foundations in Sweden, Germany, and the Netherlands were established to serve different functions than in Canada. Today, their challenges, opportunities, assets, sizes, and expenditures vary greatly and offer meaningful lessons for the Canadian contexts. Given that Canadian foundations are slated to play a more important and visible role in the future, it is crucial to understand what this future direction may look like. Much information about the Canadian grantmaking foundation landscape remains unknown. Future research can conduct case studies of similar foundations in Canada and in the European context and examine the reach and impacts that each is able to make. Moreover, scholarship would be well served by developing more standardized metrics by which to compare and contrast the Canadian sector with other comparative contexts.

\section{NOTES}

1. There are other entities in Canada that refer to themselves as "foundations," but do not have charitable status, including some public-sector grantmakers, think tanks, and foundations allied with professional associations.

2. Despite the presence of these regulatory restrictions, however, grantmaking in Canada has still grown enormously and is about at par with U.S.

3. SSHRC is the Canadian federal research-funding agency that promotes and supports postsecondary-based research and research training in the humanities and social sciences. It supports research initiatives on Canadian innovation, and its grants are distributed primarily with the aim of strongly enhancing Canada's economy, society, and/or environment within the next 10 years.

4. The other three clusters were charged with the following objectives: Cluster 1 was charged with surveying the available literature on grantmaking foundations in Canada, assessing their role in Canadian society, and evaluating the state of the empirical work to date in order to inform the goals and activities undertaken by Canadian grantmaking foundations. Cluster 2 was responsible for identifying the governance and policy issues that define, constrain, and/or enhance the societal impact of grantmaking foundations. Cluster 3 examined case studies that involve collaboration, either strictly between grantmaking foundations (GMFs) or involving other community, government, or private-sector stakeholders. Ultimately, they were tasked with creating a typology, identifying key characteristics, and measuring social impact.

5. For the comparative purposes of this analysis, the foundation sectors in Sweden, Germany, and the Netherlands are referred to as the nonprofit sectors. The nonprofit sectors in these countries are useful examples because they are dedicated to charitable goals. They are more likely than in Canada, however, to be connected to a veto player (such as a government or a private institution) that should in theory limit the ability of a foundation to autonomously control its objectives, policies, or activities. It is important to note, however, that a small number, but certainly some Canadian foundations are publicly financed, or otherwise financed from non-philanthropic resources. They provide crucial lessons learned about regulation, however, because there is actually very little regulatory intervention that impedes the foundation sectors in these countries to thrive.

6. Interview with Mark Blumberg.

7. The reasoning provided was as follows: "It is the Canada Revenue Agency's (CRA) position that the Humane Society of Canada for the Protection of Animals and the Environment (the Organization) has not devoted all of its resources to charitable activities for which it was registered. The Humane Society of Canada for the Protection of Animals and the Environment, for example, had its charitable registration revoked. This may, however, have been justified, given that the regulation of any sector is arguably necessary in a well-functioning democracy. The Organization has conferred an undue benefit on a member of its governing board, improperly completed its information return, and failed to maintain adequate books and records to support its activities. For all of these reasons, and for each of these rea- 


\section{Lajevardi, Bussell, Stauch, \& Rigillo (2017)}

sons alone, it is the position of CRA that the Organization's registration should be revoked" (Canada Revenue Agency, 2016).

8. Putnam (1993, p. 19) defines social capital as "connections among individuals-social networks and the norms of reciprocity and trustworthiness that arise from them." Social capital is a key component to building and maintaining a healthy democracy.

9. These measures are not standardized because they are collected from a secondary source.

10. Statistics on the number of foundations are scarce in this field and many changes have occurred as new laws on foundations come into effect (Wijkström \& Einarsson, 2004).

11. Statistics on the number of foundations are scarce in this field and many changes have occurred as new laws on foundations come into effect (Wijkström \& Einarsson 2005).

12. It is important to note that a small number of Canadian foundations are publicly financed as well.

13. Qualified donees are a limited set of organizations including Canadian registered charities, bodies performing a function of public government, certain universities outside Canada, the United Nations and its agencies, and a few foreign charities (Blumberg, 2009).

\section{REFERENCES}

Anheier, H.K. (2001). Foundations in Europe: A comparative perspective. London, UK: Centre for Civil Society, London School of Economics and Political Science.

Anheier, H.K., \& Hoelscher, M. (2015). Cultural sustainability in small and medium-sized cities. Culture and Sustainability in European Cities: Imagining Europolis. Routledge.

Beeby, Dean. (2016). Charities push back against Liberals on political audits. CBC News. URL: http://www.cbc.ca /news/politics/charities-push-back-against-liberals-on-politicalaudits-1.3490988 [May 21, 2016].

Burger, A., \& Dekker, P. (2001). The nonprofit sector in the Netherlands. Sociaal en Cultureel Planbureau.

Canada. (n.d.). Minister of national revenue mandate letter. Justin Trudeau, Prime Minister of Canada. URL: https://pm.gc.ca/eng/minister-national-revenue-mandate-letter [November 12, 2015].

Canada Revenue Agency. Summary of reasons for revocation - Humane Society of Canada for the Protectin of Animals and the Environment. URL: http://fairquestions.typepad.com/files/3-humane-soiety-of-canada-for-theprotection-of-animals-the-environment-h.pdf [July 27, 2016].

Carlsson, Fredrik, Johansson-Stenman, Olof, \& Martinsson, Peter. (2003). Do you enjoy having more than others? Survey evidence of positional goods. Working Papers in Economics 100. Sweden: University of Gothenburg, Department of Economics.

Council on Foundation. (2017). Canada. URL: https://www.cof.org/content/canada [January 7, 2016].

Daalder, H. (1984). In search of the center of European party systems. American Political Science Review, 78(01), 92-109.

Emmet, Brian, \& MacDonald, Emmet. (2016). What does the charitable sector have to offer? A response to the Federal Budget? Imagine Canada. URL: http://www.imaginecanada.ca/blog/what-does-charitable-sector-have-offerresponse-federal-budget [March 24, 2016].

Golombek, Jaimie. (2016). Why killing the charitable donation tax rule sends a troubling message. Financial Post. URL: http://business.financialpost.com/personal-finance/taxes/why-killingthe-charitable-donation-tax-rule-sends -a-troubling-message [May 21, 2016].

Imagine Canada. (2014). News. URL: http://www.imaginecanada.ca/who-we-are/whats-new/news/new-data-shows -canada's-largest-foundations-give-over-1-billion-annually

Lijphart, A. (1968). Typologies of democratic systems. Comparative political studies, 1(1), 3-44.

Lundström, T., \& Wijkström, F. (1997). The nonprofit sector in Sweden. Manchester, UK: Manchester University Press. 


\section{Lajevardi, Bussell, Stauch, \& Rigillo (2017)}

McGann, J.G., \& Johnson, E.C. (2005). Comparative think tanks, politics and public policy. Cheltenham, UK: Edward Elgar Publishing.

Monitor Institute (2014). What's next for community philanthropy. URL: http://monitorinstitute.com/community philanthropy/site/wp-content/uploads/2014/07/Overview.pdf [April, 2015].

Moreno, Esperanza, \& Plewes, Betty. (2007). Thinking globally? Canadian foundations and trends in international philanthropy. The Philanthropist, 21(2), 151-68.

Observatoire de la Fondation de France/CERPhi. (2015). An overview of philanthropy in Europe. European Foundation Centre. URL: http://efc.issuelab.org/resource/an_overview_of_philanthropy_in_europe [April, 2015].

Pearson, Hilary, \& Patten, Monica. (2010). Canada. In Global institutional philanthropy: A preliminary status report part II: Country profiles. WINGS Global Institutional Philanthropy: Country Reports. São Paulo, BR: TPI/WINGS Publication.

Philanthropic Foundations Canada. (n.d.). Canadian foundation facts. URL: http://pfc.ca/canadian-foundation-facts/ [September 23, 2016].

Putnam, R.D. (1993). The prosperous community. The American Prospect, 4(13), 35-42.

Salamon, Lester M., \& Anheier, Helmut K. (1998). Social origins of civil society: Explaining the nonprofit sector crossnationally. Voluntas: International journal of voluntary and nonprofit organizations, 9(3), 213-248.

Schlüter, A., Then, V., \& Walkenhorst, P. (Eds.). (2001). Foundations in Europe. Brookings Inst Press.

Schuyt, Theo, NM, Gouwenberg, B., \& Bekkers, R.H.F.P. (2011). Giving in the Netherlands: Donations, bequests, sponsorship and volunteering. URL: http://test.giving.nl/wp-content/uploads/2015/04/GIN2015_summary.pdf [April, 2015].

Study on Volunteering in the European Union Country Report Sweden. (2009) Citizenship. URL: http://ec.europa.eu /citizenship/pdf/national_report_se_en.pdf [April, 2015].

Veldheer, V., \& Burger, A. (1999). History of the nonprofit sector in the Netherlands. Baltimore, MD: Johns Hopkins Center for Civil Society Studies.

Wijkström, F., \& Einarsson, S. (2004). Foundations in Sweden: Their scope, roles and visions. Stockholm, SE: Economic Research Institute, Stockholm School of Economics.

Wolf, Miriam. (2014). The state of social entrepreneurship in Germany: SEFOR/S country report. Hertie School of Governance. URL: https://static1.squarespace.com/static/56d2eebbb654f9329ddbd20e/t/5773e6699f7456f692f 91e87/1467213419285/Country_Report_Germany.pdf [April 2014].

Zimmer, A., \& Bräuer, S. (2014). The development of social entrepreneurs in Germany. Münster: Institut für Politikwissenschaften.

Zimmer, A., Appel, A., Dittrich, C., Lange, C., Sittermann, B., Stallmann, F., \& Kendall, J. (2005). The third sector and the policy process in Germany. Third Sector European Policy Working Paper, 9, p. 13.

\section{ABOUT THE AUTHORS / LES AUTEURS}

Nazita Lajevardi is Assistant Professor of Political Science at Michigan State University. She works on issues of race, representation, inequality, and advocacy. Email: nazita@msu.edu.

Mirle Rabinowitz Bussell, PhD is a faculty member in the Urban Studies and Planning Program at UC San Diego where she is also the associate director of the Bioregional Center for Sustainability Science, Planning and Design. Email: mbussell@mail.ucsd.edu.

James Stauch is Director of the Institute for Community Prosperity at Mount Royal University. Email: jstauch@mtroyal.ca.

Nicole Rigillo is a Postdoctorial fellow in the Department of Anthropology at the University of Edinburgh and the Indian Institute of Management, Bangalore. Her research interests centre aound social welfare, volunteerism, and philanthropy in India. Email: nicole.rigillo@iimb.ac.in 